\title{
Biodegradation of Synthetic Dyes of Textile Effluent by Microorganisms: An Environmentally and Economically Sustainable Approach
}

\author{
Radia Jamee and Romana Siddique* \\ Biotechnology Programme, Department of Mathematics and Natural Sciences, BRAC University, 66 Mohakhali, Dhaka-1212, \\ Bangladesh
}

Received: 06 Aug 2019; accepted: 13 Aug 2019

\begin{abstract}
Due to its overall environmental impact, the residual dye in the wastewater from the synthetic dye manufacturing and textile industries is a global concern. The discharge contains a high content of pigments and other additives, possessing complex structures. As per the requirement for dyed clothing, dyestuff in the effluent is less susceptible to acids, bases, and oxygen. Thus, conventional physical and chemical methods are not always efficient in degrading the dyes. Some microorganisms growing in an area affected with textile effluent have the capability to utilize the dyes as a source of carbon or nitrogen or both. As a very clean, inexpensive, and sufficient alternative, bioremediation of textile wastewater using these microorganisms has gained major popularity. This review primarily centers the contribution of bacteria in this sector and the isolation of such bacteria from textile effluent. A secondary focus is discussing the factors which influence the performance by different bacteria.
\end{abstract}

Keywords: textile industry, Azo dyes, biodegradation

\section{Introduction}

Prior to 1856, dyes were prepared from natural sources such as flowers, vegetables, woods, root, insects, etc. However, with the increasing needs and demands, industries became dependent on dyes manufactured from petrochemicals, i.e., synthetic dyes. These dyes are soluble in water, easily absorbed, and very fast in coloration as compared to the natural dyes and provide a large versatility in colors [1]. In the current picture, the worldwide production of dyes is nearly 800,000 tons per year. A large amount of dyes produced is used in textile industries. Textile processing is water-intensive, releasing a huge amount of wastewater. Unfortunately, incomplete exhaustion of dyes onto textile fiber from an aqueous dyeing process leads to a major fraction of dyestuff being released with the wastewater [2]. The released wastewater contaminates water and soil, resulting in a considerable amount of environmental pollution. In addition, it can alter oxygen levels and $\mathrm{pH}$, can impede the penetration of light in the water causing disruption of the aquatic ecosystem, and is potentially toxic and mutagenic to aquatic flora and fauna. Several human health impacts are also associated with the residual dyestuff including irritation, respiratory problems, and effects on the immune system.

Colored wastewater released from the textile industries can contain between 10 and $200 \mathrm{mg} / \mathrm{L}$ of dye and a mixture of other organic and inorganic chemicals and additives [3]. In fact, even after effluent treatments, as much as $90 \%$ of these dyes are estimated to still get discharged into rivers were chemically unchanged. The decomposition of dye molecules depends on the complexity of the dye structures. Classified on the basis of their chemical composition, they can be acid dyes, azo dyes, basic dyes, disperse dyes, sulfur dyes, pigment dyes, etc. About $70 \%$ of dyes used in textile industries are azo, a

*Author for correspondence: E-mail: rsiddique@bracu.ac.bd dye complex in structure. Azo dyes contain diazotized amine coupled with an amine or phenol and one or more azo groups $(-\mathrm{N}=\mathrm{N}-)$. They are cost-effective and easy to use, which make them the most popular synthetic dye. The use of bacterial methods can be useful in degrading synthetic dyes, including azo dyes. The use of microorganisms for biodegradation is convenient because it is versatile, has dynamic metabolisms, and has potential machinery of enzymes. Bioremediation is a nonhazardous, cost-efficient, environment-friendly, and often more effective alternative to conventional methods for the treatment of textile waste. This review discusses the mechanism of degradation of synthetic dyes by microorganisms, as well as isolation and screening of microorganisms capable of decolorizing textile effluents.

\section{Microorganisms for Dye Removal from Textile Wastewater}

The treatment of textile effluent may follow several physical or chemical methods (Figure 1). Nevertheless, the use of microorganisms or microbial enzymes or the combination of this with a physicochemical method offers a better result with economic viability. The use of microbes does not only ensure a non-toxic process but also have the capability to decolorize very complex synthetic dyes.

The activity and flexibility of microorganisms determine the effectiveness of the treatment of the dyestuff. Textile dyes are decolorized by microorganisms in two major ways, either adsorption on microbial biomass or biodegradation of dyes by the cells or enzymes. The use of biomass is particularly useful if the effluent is highly toxic and does not support the growth and maintenance of microbial cells. Adsorbents can include bacteria, microalgae, and fungi, and the adsorption does not degrade the dye into fragments. In contrast to biosorption, the original dye structure is disrupted in biodegradation, often entirely decomposed. Thus, biodegradation is the more practical option [5].

This is an open-access article distributed under the terms of the Creative Commons Attribution-NonCommercial 4.0 International License (https://creativecommons.org/licenses/by-nc/4.0/), which permits unrestricted use, distribution, and reproduction in any medium for non-commercial purposes, provided the original author and source are credited, a link to the CC License is provided, and changes - if any - are indicated. 


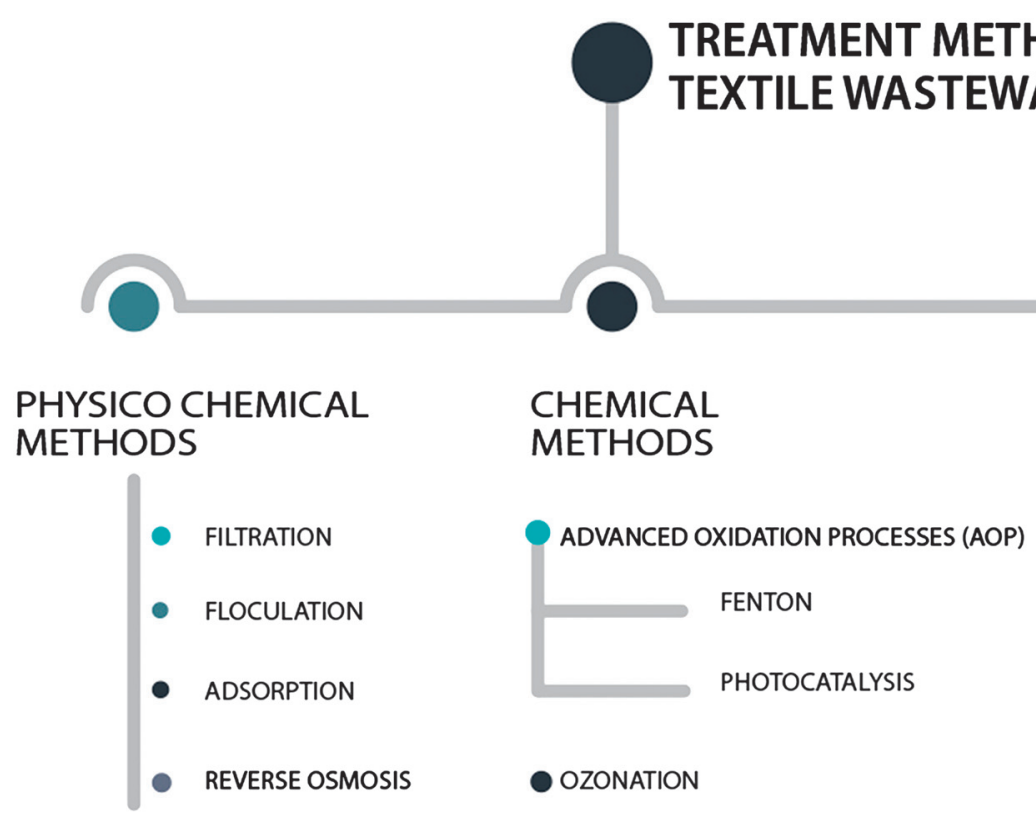
METHODS FOR TEXTILE WASTEWATER

\section{PHYSICO CHEMICAL METHODS}

\author{
- FILTRATION \\ - FLOCULATION \\ - ADSORPTION \\ - REVERSE OSMOSIS
}

CHEMICAL METHODS

ADVANCED OXIDATION PROCESSES (AOP)

FENTON
PHOTOCATALYSIS

BIOLOGICAL METHODS

ENZYMES

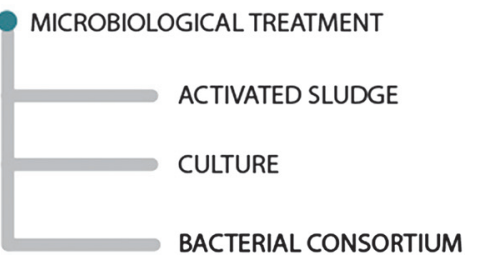

Figure 1. Treatment methods for dye removal from textile effluent [4]

Degradation of Dyes by Fungi. Extensive studies have been conducted on white-rot fungi for the mineralization of synthetic dyes. They produce various extracellular oxidoreductases that degrade lignin and related aromatic compounds. Its structurally nonspecific and nonstereoselective enzyme system includes lignin peroxidase (LiP), manganese peroxidase $(\mathrm{MnP})$, and laccase. Production of laccase by Phanerochaete chrysosporium and Neurospora crassa has been extensively studied for removal of pigments and phenol from liquid waste [6]. Trametes versicolor, Bjerkandera adusta, Aspergillus ochraceus, species of Pleurotus and Phlebia, etc. have also gained much attention [7]. By using gel entrapment and adherence to a matrix, encouraging results can be obtained for the wastewater treatment [6].

In spite of the success, the fact that white-rot fungi are not naturally found in wastewater makes the enzyme production unreliable. In addition to that, some other disadvantages are associated with using white-rot fungi, i.e., long growth cycle and the dependency on nutrient limitation. The decolorization is also limited by the long hydraulic retention time required for complete decolorization [5].

Degradation of Dyes by Yeasts. Biological decolorization of azo dyes by yeasts is mediated by azoreductases in yeasts which catalyze reductive cleavage of azo groups $(-\mathrm{N}=\mathrm{N}-)$. Example of such yeasts includes Candida oleophila and Candida zeylanoides. Decolorization by these strains is due to azo bond reduction, forming the corresponding amines. A study of the enzymes responsible for the biodegradation of Methyl Red by Saccharomyces cerevisiae MTCC 463 showed different levels of the activities of laccase, lignin peroxidase, NADH-DCIP reductase, azoreductase, tyrosinase, and aminopyrine $N$-demethylase. It is suggested by studies that these products are further degraded into aliphatic amines that might be facilitated by oxidative enzymes such as lignin peroxidase and laccase [8]. S. cerevisiae cells have also shown bioaccumulation of reactive textile dye (Remazol Blue, Remazol Black B, and Remazol Red RB) during growth in molasses. Some ascomycete yeast species, such as Candida tropicalis, Debaryomyces polymorphus, and Issatchenkia occidentalis, have been studied to decolorize azo dyes. Galactomyces geotrichum MTCC 1360 can decolorize azo and reactive high exhaust textile dyes [7]. Trichosporon beigelii has shown to have the capability to degrade Navy blue HER up to $100 \%$ [5].

Degradation of Dyes by Algae and Plants. Studies suggest that photosynthetic organisms like algae and cyanobacteria are capable of degrading azo dyes through an induced form of azoreductase [9]. Algae are mostly used in biosorption. Several species of Chlorella and Oscillatoria are able to degrade azo dyes to their aromatic amines and to further metabolize the aromatic amines into simpler organic compounds or $\mathrm{CO}_{2}$ [7].

Using plants for the process, better known as phytoremediation, has a major advantage, which is the limited need for nutrient supplies. Brassica juncea, Sorghum vulgare, and Phaseolus mungo have successfully decolorized textile effluents up to 79, 57, and 53\%, respectively [7]. Blumea malcommi and Tagetes patula have also given positive results in the literature. However, there are some drawbacks - the requirement of the area in order for the treatment to be functional and the impact of pollution on plants.

Degradation of Dyes by Bacteria. Bacterial oxidoreductive enzymes are the key to the degradation of synthetic dyes. This dynamic metabolism of bacteria enables them to utilize complex xenobiotic compounds of the dyestuff as a substrate. In the process, they are broken down to less complex metabolites. An advantage of obtaining bacteria from actual sites of wastewater disposal is that they are more likely to have the enzymes activated, which facilitate the decomposition of dyes.

\section{Pure Bacterial Cultures}

Starting from the 1970s, Bacillus cereus, Bacillus subtilis, and Aeromonas hydrophila were marked as potential remediators on the basis of various studies [10]. Textile effluents contain a pool of structurally complex synthetic dyes and other chemicals, which when released into water bodies, reduced dissolved oxygen concentrations, creating anoxic conditions that are toxic for most organisms. Recent research studies on cultures of Proteus mirabilis, Pseudomonas luteola, and Pseudomonas sp. have shown promising results for azo dye degradation under anoxic conditions [11, 12, 13]. 


\section{Mixed Bacterial Cultures}

Isolation of pure cultures from textile wastewater can be time-consuming and laborious. In addition, it is difficult to obtain complete decolorization by a pure bacterial culture. Mixed bacterial cultures, due to their cooperation for an enhanced effect, provide better results in decolorization and mineralization. They can efficiently degrade toxic aromatic amines. Nonetheless, the fact that these results are not readily reproduced and that mixed cultures do not provide the exact view of the dye metabolism makes the process and the results hard to interpret [7].

\section{Bacterial Methods for Decomposition of Dyestuff}

The degradation of synthetic dyes by bacteria is facilitated by their oxidases. In the case of azo dyes, azoreductase plays the most vital role in decolorization by breaking down azo bonds. Some bacteria have been studied to degrade dyes under aerobic condition. Aerobic conditions facilitate mono- and dioxygenase enzymes to catalyze the incorporation of oxygen from $\mathrm{O}_{2}$ into the aromatic ring of organic compounds [14]. Some aerobic bacteria reduce azo compounds with the help of oxygen catalyzed azoreductases [15].

Decolorization under Anaerobic Conditions. For azo dye degradation, the enzyme azoreductase functions under anaerobic conditions. Nicotinamide adenine dinucleotide (NADH) and flavin adenine dinucleotide (FADH) are the reducing agents. Intermediates formed in the process are degraded aerobically or anaerobically. Studies suggest that oxygen may inhibit the azo bond reduction activity, since aerobic respiration utilizes $\mathrm{NADH}$, thus impeding the electron transfer from NADH to azo bonds. Alternatively, decolorization might be attributed to nonspecific extracellular reactions occurring between reduced compounds generated by the anaerobic biomass. Decolorization is mediated by methanogens and acidogenic, as well as methanogenic bacteria, under anaerobic conditions [5]. It is a nonspecific process, depending on the carbon source and the dye structure. Some bacteria taking part in the decolorization process could grow aerobically; however, decolorization is achieved only under anaerobic conditions. Dye decolorization reactions usually follow first-order kinetics with respect to dye concentration. Zero-order kinetics has also been observed [16].

Decolorization under Anoxic Conditions. Whereas anaerobic conditions are entirely free from oxygen, anoxic conditions have less than $0.5 \mathrm{mg} / \mathrm{L}$ dissolved oxygen. Operating conditions for these are similar to aerobic treatments. Under anoxic conditions, nicotinamide adenine dinucleotide phosphate (NADPH) carries more electrons for reduction. Mixed bacterial populations of aerobic and facultative anaerobic have been shown to be useful in anoxic decolorization of various dyes [16]. This requires complex organic sources, such as yeast extract, peptone, etc., which increases the cost.

Decolorization under Aerobic Conditions. Most bacteria that degrade dyes under aerobic conditions cannot utilize the dye as a carbon source and require an additional carbon source. Very few bacteria are capable of growing on azo compounds as the sole carbon source. These bacteria are able to cleave $-\mathrm{N}=\mathrm{N}-$ bonds and utilize amines for their growth, for instance, Pigmentiphaga kullae K24 and Xenophilus azovorans KF 46. Aerobic bacteria possess oxidoreductive enzymes and can break the dye molecules symmetrically or asymmetrically. They could also bring about deamination, desulfonation, hydroxylation, etc. Therefore, different dye structures can be broken down by anaerobic bacteria.

\section{Isolation and Screening of Textile Dye Degrading Bacteria}

Depending on the sample, nutritional requirements, and targeted dyes, the process selected for isolation of bacteria may vary. Experimental dyes should be stored at room temperature. $1 \%$ stock solutions are prepared by dissolving $1 \mathrm{~g}$ of each powder dye into $100 \mathrm{~mL}$ of autoclaved distilled water, followed by filtration. The samples may be collected from suitable sites of textile effluent disposal. The next step is the growth and selection of bacteria capable of decolorization. Several methods can be employed for this step. This paper discusses the most basic, commonly used methodologies.

\section{Growth and Selection}

Enrichment Culture of Sample. In this method, the sample is grown in a nutrient medium supplemented with the experimental dye. The choice of media depends upon growth requirements of the bacteria in the sample. Nutrient broth supplemented with a concentration of $1 \%$ dye is suitable for many bacteria [17]. Bushnell Haas (BH) medium composed of $\mathrm{KH}_{2} \mathrm{PO}_{4} \quad 0.1 \%, \mathrm{~K}_{2} \mathrm{HPO}_{4} \quad 0.1 \%, \mathrm{MgSO}_{4} \cdot 7 \mathrm{H}_{2} \mathrm{O} \quad 0.02 \%$, $\mathrm{CaCl}_{2} \cdot 2 \mathrm{H}_{2} \mathrm{O} \quad 0.002 \%, \mathrm{NH}_{4} \mathrm{Cl} \quad 0.1 \%, \mathrm{NH}_{4} \mathrm{NO}_{3} \quad 0.1 \%, \mathrm{NaCl}$ $0.01 \%$, and $\mathrm{FeCl}_{3}-6 \mathrm{H}_{2} \mathrm{O} 0.005 \%$ at $\mathrm{pH} 7$ may be used [18]. Mineral salts medium (MSM) containing $\mathrm{Na}_{2} \mathrm{HPO}_{4}(3.6 \mathrm{~g}$ ), $\left(\mathrm{NH}_{4}\right) 2 \mathrm{SO}_{4}(1.0 \mathrm{~g}), \mathrm{KH}_{2} \mathrm{PO}_{4}(1.0 \mathrm{~g}), \mathrm{MgSO}_{4}(1.0 \mathrm{~g}), \mathrm{Fe}\left(\mathrm{NH}_{4}\right)$ citrate $(0.01 \mathrm{~g}), \mathrm{CaCl}_{2} \cdot 2 \mathrm{H}_{2} \mathrm{O}(0.10 \mathrm{~g})$ and $10.0 \mathrm{~mL}$ of trace element solution per liter may also be used [19]. For enrichment of dye decolorizing bacteria, the effluent sample and dye mixture must be added to a conical flask containing suitable media, incubated under suitable conditions (e.g., $\left.37{ }^{\circ} \mathrm{C}, 100-150 \mathrm{rpm}\right)$. Media must be supplemented with glucose, yeast extract, etc. if the sample microorganisms are unable to use the dye as a carbon source.

Following the incubation, the solution is monitored for decolorization at predetermined intervals (e.g., $6 \mathrm{~h}$ ). For positive results with sample for a certain dye, results are confirmed for individual colonies using a plate method on a screening medium.

Serial Dilution of Sample. The sample collected from a contaminated site can be textile effluent or soil affected by the effluent. The sample should be diluted with sterile distilled water or sterile saline solution. Each dilution should be then spread or streaked on nutrient agar plates at an optimum temperature for $24 \mathrm{~h}$. Pure colonies are then isolated, and the isolates must be tested for their ability to decolorize dyes in media supplemented with dyes [20].

The bacteria can be identified by biochemical tests, genomic DNA, or 16S rRNA.

\section{Quantification of Dye Decolorization}

Decolorization should be determined by measuring the absorbance of culture supernatants at absorbance maxima of respective dyes after centrifugation at $10,000 \mathrm{rpm}$ for $15 \mathrm{~min}$ [21].

Decolorization $\%=($ initial absorbance - final absorbance $) /$ initial absorbance $\times 100$.

\section{Screening for Enzymes}

Screening medium supplemented with $0.01 \%$ experimental dye should be prepared. About $10 \mu \mathrm{L}$ of supernatant should be added into the well (about $5 \mathrm{~mm}$ ) cut in the screening medium. Zone sizes must be measured following incubation under optimum conditions for $24 \mathrm{~h}$. For positive results, the crude enzyme in supernatant must be purified and further experimented [22]. 


\section{Factors Influencing the Performance by Bacteria in Decolorization}

Biodegradation of synthetic dyes and other chemicals in textile effluent depends on the physical, chemical, and biological processes, as well as some environmental factors.

Dye Structure. Dyes with simpler structures and low molecular weights exhibit higher rates of color removal. The nature of substituents on the aromatic ring has been shown to have an impact on oxidation. Studies have demonstrated that electron-donating methyl and methoxy substituents enhance the enzymatic degradation of azo phenols, while electronwithdrawing chloro, fluoro, and nitro substituents inhibit oxidation [6].

Dye Concentration. According to a study, increasing the dye concentration gradually decreases the decolorization rate. This may be due to the toxic effect of dyes on the microorganisms. Several other possible reasons could be inadequate cell to dye ratio, as well as blockage of active sites of azoreductase by dye molecules with different structures $[23,24,25,26,27]$.

Carbon and Nitrogen Sources. Most microorganisms generally cannot utilize dyes as a carbon and/or a nitrogen source for growth. Such bacterial cultures require a carbohydrate source, or complex organic sources, such as yeast extract, peptone, or a combination of both for the decomposition [5].

Temperature and pH. Decolorization rate is higher at optimal $\mathrm{pH}$ and decreases at a more acidic or alkaline $\mathrm{pH}$. Textile industrial processes take place mosotly under alkaline conditions; thus, the tolerance to high $\mathrm{pH}$ is important in particular. The optimal often being between 6.0 and 10.0 [7].

Very high temperatures can be associated with denaturation of azoreductases. It is observed that increasing temperature in a certain range (optimum) increases the decolorization rate. Increasing the temperature further drastically decreases the rate.

Dissolved Oxygen. Different groups of bacteria decolorize dyes under anaerobic, facultative anaerobic, and aerobic conditions. For those operating under anaerobic conditions, reductive enzyme activities are higher in anoxic conditions, which break down the structure of the synthetic dyes. Dissolved oxygen is considered an inhibitor of the azo dye reduction process, since both molecules act as electron acceptors and oxygen is a much stronger oxidant [8].

\section{Conclusion}

Textile wastewater requires appropriate treatment prior to their release into the environment. Residual dyes have complex structural compositions which are toxic for the organisms in soil and water of the affected area. The industries need a cost-efficient and feasible method to treat their effluents, so that when released into the water bodies, it will have little impact on the environment. Microbial and enzymatic decomposition of the wastewater is a viable option, as they do not produce large amounts of sludge, have no adverse effect on the environment, and are inexpensive. On the basis of available literature studies, several lab-based study findings have been explored in this review. Nevertheless, relative data of the performance of isolated microorganisms at an industrial level requires to be generated. It is crucial to optimize all the parameters in order to achieve maximum decolorization by isolated bacterial strains. There is scope for studies on scaling-up of the successful laboratory experiments with newly identified bacteria for future implementation in industries. Experiments should be conducted to measure the toxicity levels in treated effluent, alongside the decolorization rate. Based on the successful laboratory results, efforts should then be made to scale up and apply bacterial decolorization techniques in real industrial effluents. In addition, with the latest advances in genomics and proteomics, there is a possibility to enhance the performance of bacterial or enzymatic treatments of textile wastewater. With all the positive research findings and ongoing developments, microbiological treatment is hoped to be predominant in the elimination of dyes and toxic chemicals in textile wastewater.

\section{Funding Sources}

No funding was provided by the university or any other agency.

\section{Authors' Contribution}

This work was carried out in collaboration between both authors. Authors RS and RJ managed the literature searches, performed the analysis, and wrote the first draft of the manuscript. Both authors read and approved the final manuscript.

\section{Conflict of Interest}

There is no conflict of interest among the authors.

\section{References}

1. Pandey AK, Sarada DV, Kumar A. Microbial Decolorization and Degradation of Reactive Red 198. Proceedings of the National Academy of Sciences, India; 2016. p. 805-15.

2. Hassaan MA, Nemr AE. Health and Environmental Impacts of Dyes: Mini Review. American J Environ Sci Eng. 2017:64-7.

3. Doble M, Kumar A. Biotreatment of Industrial Effluents. Resour Conserv Recycl. 2007:507-8.

4. Sala M, Gutiérrez-Bouzán MC. Electrochemical Techniques in Textile Processes and Wastewater Treatment. Int J Photoenergy. 2012.

5. Khan R, Bhawana P, Fulekar MH. Microbial decolorization and degradation of synthetic dyes: A review. Rev Environ Sci Bio/Technol. 2013:75-97.

6. Singh L, Singh VP. Textile Dyes Degradation: A Microbial Approach for Biodegradation of Pollutants. In Microbial Degradation of Synthetic dyes in Waste waters, Environmental Science and Engineering. Springer International Publishing Switzerland; 2015.

7. Saratale RG, Saratale GD, Chang JS, Govindwar SP. Bacterial decolorization and degradation of azo dyes: A review. J Taiwan Inst Chem Eng. 2011:138-57.

8. Jafaria N, Soudib MR, Kasra-Kermanshahi R. Biodegradation Perspectives of Azo Dyes by Yeasts. Microbiology. 2014:484-97.

9. Vijayaraghavan K, Yun Y. A Study on Biosorption Potential of Aspergillus sp. of Tannery Effluent. Adv Biosci Biotechnol. 2014:266-91.

10. Wuhrmann $\mathrm{K}$, Mechsner $\mathrm{K}$, Kappeler $\mathrm{T}$. Investigations on rate determining factors in the microbial reduction of Azo Dyes. Eur J Appl Microbiol Biotechnol. 1980;9:325-38.

11. Chang JS, Chou C, Lin Y, Ho J, Hu TL. Kinetic Characteristics of Bacterial Azo Dye Decolorization by Pseudomonas luteola. Water Res. 2001b;35:2041.

12. Chen KC, Huang WT, Wu JY, Houng JY. Microbial Decolorization of Azo Dye by Proteus mirabilis. J Ind Microbiol Biotechnol. 1999;23:686.

13. Kalyani DC, Telke AA, Dhanve RS, Jadhav JP. Ecofriendly Biodegradation and Detoxification of Reactive Red 2 Textile Dye by Newly Isolated Pseudomonas sp. SUK1. J Hazard Mater, 2008;163:735.

14. Sarayu K, Sandhya S. Aerobic biodegradation pathway for Remazol Orange by Pseudomonas aeruginosa. Appl Biochem Biotechnol, 2010:124153.

15. Lin J, Zhang X, Li Z, Lei L. Biodegradation of Reactive Blue 13 in a Two-Stage anaerobic/aerobic fluidized beds system with a Pseudomonas sp. isolate. Bioresour Technol. 2010:34-40.

16. Khandare RV, Govindwar SP. Microbial Degradation Mechanism of Textile Dye and Its Metabolic Pathway for Environmental Safety. In Chandra R, editor. Environmental Waste Management. CRC Press; 2015.

17. Vimala G, Jeyakumar P, Devi C, Singh A, Iyer P. Azo Dye Degrading Bacteria from Textile Effluent. Int J Curr Microbiol Appl Sci. 2015:199-210.

18. Karim ME, Dhar K, Hossain MT. Decolorization of Textile Reactive Dyes by Bacterial Monoculture and Consortium Screened from Textile Dyeing Effluent. J Genet Eng Biotechnol. 2018:375-80.

19. Khehra MS, Saini HS, Sharma DK, Chadha BS, Chimni SS. Decolorization of various azo dyes by bacterial consortium. Dyes Pigements. 2005:55-61.

20. Khalid T, Fatima A, Shafiq A, Javed S, Nadeem SG. Microbial Decolorization of Textile Effluent. RADS J Biol Res Appl Sci. 2016:28-34.

21. Moosvi S, Kher X, Madamwar D. Isolation, characterization and decolorization of textile dyes by a mixed bacterial consortium JW-2. Dyes Pigments. 2007:723-729. 
22. Kumar NM, Saravanan D. Isolation of dye degrading bacteria from textile effluent. J Chem Pharm Res, 2015:2214-18.

23. Jadhav SU, Jadhav MU, Kagalkar AN, Govindwar SP. Decolorization of Brilliant Blue G Dye Mediated by Degradation of the Microbial Consortium of Galactomyces geotrichum and Bacillus sp. J Chin Inst Chem Engrs, 2008;39:563

24. Sani RK, Banerjee UC Decolorization of Triphenylmethane Dyes and Textile and Dyestuff Effluent by Kurthia sp, Enzyme Microb Technol. 1999;24:433.
25. Saratale RG, Saratale GD, Chang JS, Govindwar SP. Ecofriendly Decolorization and Degradation of Reactive Green 19A Using Micrococcus glutamicus NCIM-2168. Bioresour Technol. 2009c;110:3897

26. Tony BD, Goyal D, Khanna S. Decolorization of Textile Azo Dyes by Aerobic Bacterial Consortium. Int Biodeter Biodegr. 2009a;63:462.

27. Tony BD, Goyal D, Khanna S. Decolorization of Direct Red 28 by Mixed Bacterial Culture in an Up-Flow Immobilized Bioreactor. J Ind Microbiol Biotechnol. 2009b;36:955. 